\title{
MARL announces 2007 Marketing Awards: You, too, can feel like a rock $\mathbf{n}^{\prime}$ roll librarian
}

T he lights dimmed, the rhythmic beat of the music began to 11 the gigantic room, and my heart began to beat faster. I felt like I was in a large dance club or concert, but when I looked down at my clenched hands I was politely dressed in trousers and a blouse instead of my usual rock $\mathrm{n}$ roll uniform of jeans and old t-shirt. But nonetheless I felt like a rock star.

When American University won the grand prize in the ACRL 2005 Best Practices in Marketing Academic and Research Libraries@your library Award, I never anticipated that we would be one of the focal points at the 2005 ACRL National Conference. After winning, ACRL asked us to create a flash presentation that highlighted our project. Our marketing team had no idea how this video would be used.We were only told the award would be presented at the conference-wide lunch. When we arrived at the ballroom we found two 20-foot screens where our video would be shown. With anticipation I waited for our segment to play. Soon electronica music that accompanied our winning campaign presentation blared through the large hall. After the video, ACRL past president Tyrone Cannon said shake @your library in reference to our heart pumping soundtrack. With a laugh, he invited us on stage.

This prize was the summation of more than two years of researching, brainstorming and planning a marketing campaign along with negotiating and editing designs. The pride I felt as the members of our marketing team took the stage was overwhelming. It started out as a project that a few of us rallied for and our University Librarian, Patricia Wand fully supported. But she didn t just support us, she allowed us to be creative, crazy risk takers. Everyone who worked on this project brought their very best knowledge to the table including: two marketing graduate students with fresh and challenging information, two senior librarians with much knowledge and many campus connections, one development of cer with amazing event planning skills and keen creativity, and one graphic designer with an almost telepathic ability to know what the team was thinking and how to manifest it with both humor and clarity. Since last year, two of our team members have become marketing directors elsewhere and both Pat and I have moved to different institutions. But the feeling of being rock stars that day remains!

\section{You could be next}

We truly rocked and now you can too, because the ACRL Marketing Academic and Research Libraries Committee has just announced that there will be a 2007 Best Practices in Marketing Academic and Research Libraries @your library Award given out at the 13th ACRL National Conference, to be held in Baltimore, Maryland, March 29 April 1, 2007. This time ACRL, with support from Springer, will honor three rst place winners who will each receive a $\$ 2,000$ prize. Each award will celebrate a different type of library: associate or community college, college and university.

Please check the ACRL Web site (www. acrl.org/marketing) for the latest information, such as criteria for judging, timeline for submission, types of materials to submitted, etc. I look forward to you applying for this award because I know that regardless if you win or not you will feel like a celebrity for choosing to promote library services, resources and values. Mary F. Evangeliste, University of Arizona, Evangelistem@u.library.arizona.edu. 